\title{
MAKING FINANCE FUN: THE GAMIFICATION OF PERSONAL FINANCIAL MANAGEMENT APPS
}

\begin{abstract}
Purpose: This study integrates self-determination theory (SDT) and the technology acceptance model (TAM) to explore how gamification increases users' motivation and intention to use personal financial management (PFM) apps, and how it facilitates their adoption.

Design/methodology/approach: Data from 208 users of the Mint app were analyzed using partial least squares structural equation modelling.

Findings: The results showed that gamifying PFM apps satisfies users' needs for competence and autonomy and enhances their autonomous motivation to use them. Users' motivation increases their perceptions of ease of use and usefulness of the apps and causes them to develop more favorable attitudes toward them. The findings also confirmed a relationship between users' attitudes toward PFM apps and the behavioral intention to use them.
\end{abstract}

Research limitations: To investigate the generalizability of results, studies using other PFM apps would be useful. The cross-sectional nature of the research also limits its causal inference.

Practical implications: This research provides support for the use of gamification in PFM apps and offers suggestions that may help fintech companies and banks to persuade users to engage with their apps.

Originality: Although gamification is a trending topic, few studies have explored its use in the finance industry. Drawing on SDT and the TAM, this study extends previous research and adds new insights into the effects of gamification in this context.

Keywords: Personal financial management apps; Gamification; Self-determination theory; TAM.

Classification: Research paper 


\section{MAKING FINANCE FUN: THE GAMIFICATION OF PERSONAL \\ FINANCIAL MANAGEMENT APPS}

\section{Introduction}

The financial industry has been one of the first to adopt mobile technologies (Jun and Palacios, 2016). In this context, finance apps have gained great popularity among consumers. In 2019, finance apps accounted for 5\% of app downloads (AppsFlyer, 2020) and were accessed over one trillion times (App Annie, 2020). Along with mobile banking and payment apps (Karjaluoto et al., 2019), personal financial management (PFM) apps are among the fastest growing categories of finance apps. The global PFM-tool market size was $\$ 1,449.9$ million in 2018 and is expected to reach $\$ 3,338.8$ million in 2025 , with a compound annual growth rate of $12.65 \%$ from 2018 to 2025 (QYResearch, 2019).

Developed by banks and fintech companies, PFM apps have changed the way consumers manage their finances. PFM apps seek to improve consumers' financial health by helping them to manage and take control of their finances. PFM apps usually consolidate users' accounts in one place, which allows them to monitor how much they earn, where, and on what, they spend their money and plan their spending, saving, and investing. The apps also help users by creating budgets, setting goals, finding ways to save, sending notifications and alerts and simplifying the investing process. Examples of

PFM apps include Mint, Personal Capital, You Need a Budget, Mvelopes, and Robinhood, among many others.

Mobile apps in the banking sector seek to improve their users' experiences (Komulainen and Saraniemi, 2019) and enhance their motivation and engagement (Garzaro et al., 2021). In common with apps in sectors such as health, sports, tourism, 
hospitality and education (e.g., Hofacker et al., 2016; Liu et al., 2019; Tu et al., 2019; Wang and Tahir, 2020), one way to achieve this is through gamification, that is, the implementation of game features and other game-like designs (Deterding et al., 2011). For instance, numerous PFM apps enable users to set savings goals and seek to motivate them to achieve these through challenges. The apps use progress bars and other performance graphs to provide financial information. In addition, some of these apps enable users to compare and/or share their financial situation and goals with their peers.

Defined from the service marketing perspective as a "process of enhancing a service with affordances for gameful experiences in order to support users' overall value creation" (Huotari and Hamari, 2017, p. 25), gamification has gained the attention of both scholars and practitioners in recent years (Koivisto and Hamari, 2019; Wünderlich et al., 2020). By creating scenarios similar to those experienced in games, gamification seeks to promote positive psychological outcomes among individuals and shape their behaviors (Koivisto and Hamari, 2019). As such, in the finance context, gamification has the potential to make financial management fun and increase consumers' financial literacy (Rodrigues et al., 2016b), that is, their understanding and use of personal finance-related information (Huston, 2010). It can also improve financial well-being and motivate their users to undertake specific behaviors, such as saving (Bayuk and Altobello, 2019).

Many studies have recognized that gamification research is largely concentrated in the domains of education and learning (Seaborn and Fels, 2015; Kasurinen and Knutas, 2018; Koivisto and Hamari, 2019). By contrast, other fields, such as finance, have received little attention, despite gamification becoming a common practice in the sector (Baptista and Oliveira, 2017). Indeed, as recently noted by Bayuk and Altobello (2019, p. 953), "academic research has only begun to explore what characteristics of the new technologies, including game features or incentives, are most effective in motivating 
individuals to save, and whether use of these financial gaming apps improves financial well-being".

Table I summarizes the relatively few studies that have explored the use of gamification in the finance industry. While these works have provided important insights into the use of gamification in the finance sector, more studies are needed to enhance this understanding. Specifically, research is mainly focused on the e-banking field (e.g., Rodrigues et al., 2016a, 2016b, 2016c; Baptista and Oliveira, 2017). Some works explore gamification only as a research context (e.g., Rodrigues et al., 2016b), so their findings, although relevant, do not allow conclusions to be drawn about how gamification influences consumers' behaviors. Furthermore, many studies do not analyze actual gamified app-user interactions. Instead, they assess how users rate game features in hypothetical financial gaming apps (e.g., Bayuk and Altobello, 2019), banking systems (Nasirzadeh and Fathian, 2020), and e-banking (e.g., Baptista and Oliveira, 2017; Rahi and Ghani, 2018, 2019).

\section{[Table I here]}

In addition to the narrow scope of domains that have been investigated, a further limitation identified by the gamification literature is its lack of theoretical foundations and its use of a limited number of theories (Seaborn and Fels, 2015; Koivisto and Hamari, 2019). Rapp et al. (2019, p. 5) noted that the human condition is, however, complex, and to ground gamification designs, "it is often necessary to draw from a variety of theoretical approaches." Without a doubt, self-determination theory (SDT; Deci, 1975) is the theoretical framework most used in gamification research (Rapp et al., 2019). Nevertheless, in the finance context, conceptual models based on the technology acceptance model (TAM; Davis, 1989) have been proposed to examine the adoption of banking services in general (e.g., Santini et al., 2019; Souiden et al., 2021) and gamified 
e-banking in particular (e.g., Rodrigues et al., 2016b, 2016c; Baptista and Oliveira, 2017). While both theories, SDT and TAM, are useful for explaining users' responses to gamified finance apps and PFM apps, in particular to the best of the authors' knowledge, no previous research has combined them in this context.

To address these gaps, this study focuses on the financial domain and integrates SDT and the TAM to explore how gamification increases users' motivation and intention to use PFM apps and how it facilitates their adoption. In particular, as shown in Figure 1, the study analyzes the effects of motivational affordances, that is, game elements, on motivational factors such as perceived competence, perceived autonomy, and autonomous motivation, and their subsequent effects on technology acceptance variables such as perceived ease of use and perceived usefulness. An exploration is then made of users' attitudes toward gamified PFM apps and their intention to use them.

\section{[Figure 1 here]}

The contribution of this study is threefold. First, although gamification research has grown over the last years, there is an underrepresentation of studies in the finance domain. In addition, given that contextual factors influence the consequences of gamification (Koivisto and Hamari, 2019), results from some fields, such as education and health, might not be relevant in others. Consequently, recent calls have highlighted the need to broaden the scope of the domains under study (Koivisto and Hamari, 2019). This research contributes to the gamification literature by adding new insights into the adoption and use of PFM apps. Second, drawing on two theories, SDT and the TAM, this research provides new insights into consumers' use of PFM apps by exploring how game features influence users' motivations and beliefs about the technologies used. Finally, the research offers practical implications for fintech companies and banks seeking to attract consumers to their gamified finance apps. 


\section{Theoretical background and research hypotheses}

Gamification applies motivational design to persuade individuals to behave in certain ways (Werbach and Hunter, 2012). Thus, understanding the individuals' motivations is key in addressing gamification effectiveness. In this regard, SDT (Deci and Ryan, 2000) has become one of the leading frameworks for gamification research (Tobon et al., 2020).

SDT distinguishes between autonomous and controlled motivation, based on whether individuals behave with a full sense of choice or under pressure (Deci and Ryan, 2015). More precisely, autonomous motivation is based on individuals behaving voluntarily, seeking fun and enjoyment (Ryan and Deci, 2000), acting in certain ways because they identify themselves with the value of the behavior, and find it personally important and valuable (Deci et al., 1996). On the other hand, controlled motivation relates to behaviors undertaken because individuals are controlled, irrespective of whether the control is exerted by external sources (e.g., to obtain a reward or to avoid punishment) or internal (e.g., to satisfy ego needs or to avoid shame) (Deci and Ryan, 2015). Of these two types of motivation, autonomous motivation is more valuable for the individual because it improves his/her performance (Gagné et al., 2015) and psychological well-being (Deci et al., 1996). SDT-based research has analyzed the factors that encourage this form of motivation, finding that autonomous motivation develops when the individual's needs for competence, that is, the feeling that (s)he has mastered his/her own actions and become skilled at an activity (White, 1959; Ryan et al., 2006), and autonomy, that is, the feeling of freedom, and of liberty to choose (de Charms, 1968), are satisfied (Ryan and Deci, 2000).

In general, research into gaming has suggested that games foster competence through challenges, rewards and feedback, and autonomy through flexibility to make choices about objectives and tasks (Ryan et al., 2006). Gamification research has also analyzed 
whether interacting with different motivational affordances/game elements (e.g., challenges, achievements, points, leaderboards, rewards, badges, progress bars, increasing difficulty levels, cooperation, competition, avatars/profiles, narratives/ meaningful stories, customization) embedded in gamified applications satisfies their users' needs for competence and autonomy. With some exceptions (e.g., Mekler et al., 2017), research has suggested that motivational affordances can help satisfy these needs. For instance, some studies have found that overcoming challenges (van Roy and Zaman, 2019; Wee and Choong, 2019), reaching increasing difficulty levels (Peng et al., 2012), receiving performance feedback (Sailer et al., 2017; Wee and Choong, 2019) and being rewarded (Peng et al., 2012; Suh et al., 2018; van Roy and Zaman, 2019) facilitate users' feelings of competence, as these game elements provide users with a sense of purpose and information on their progress (Sailer et al., 2013). In the same vein, facing challenges (van Roy and Zaman, 2019) and receiving rewards (Suh et al., 2018) have been shown to give users a sense of autonomy as they provide flexibility and choice over tasks. Although some studies have suggested that neither competition nor cooperation with teammates facilitates feelings of competence and autonomy (Sailer et al., 2017; Bitrián et al., 2020), others have argued that competition (Suh et al., 2018; van Roy and Zaman, 2019; Xi and Hamari, 2019), cooperation, and social networking features (Xi and Hamari, 2019) can satisfy these needs. Similarly, with some exceptions (Sailer et al., 2017; Xi and Hamari, 2019), most studies have found that motivational affordances related to customization, avatars, and meaningful stories are positively associated with higher levels of competence (Wee and Choong, 2019; Bitrián et al., 2020) and autonomy (Peng et al., 2012; Suh et al., 2018; Wee and Choong, 2019; Xi and Hamari, 2019; Bitrián et al., 2020), as having the possibility to personalize profiles and activities enables users to make their own decisions (Sailer et al., 2013; Kim et al., 2015). 
As noted earlier, more and more PFM apps are using gamification to enhance their users' experiences. Some apps offer users the possibility to set financial goals and take on personal challenges related to achieving a certain level of savings and reducing expenses in one specific category. In addition, they include real-time tracking of financials, usually depicted in the form of progression charts, so users can monitor their ongoing success toward meeting their goals. They also provide feedback to users in the form of alerts and notifications regarding expenditure, account balances, upcoming bills, etc. Finally, as these apps are individually tailored to each user's needs (e.g., budgeting, planning, investing), they allow customers to personalize their experiences. Based on the arguments set out above, we expect that the motivational affordance-user interaction included within gamified PFM apps will increase their users' perceptions of competence and autonomy. Accordingly, the following hypotheses are proposed:

H1. Users' interactions with motivational affordances in gamified PFM apps positively influences their perceptions of (a) competence and (b) autonomy.

SDT proposes that contexts that facilitate the satisfaction of competence and autonomy foster users' autonomous motivation (Deci and Ryan, 2000; Ryan and Deci, 2000). The relationship between need satisfaction and autonomous motivation has been explored in the gamification domain. For instance, research analyzing the use of gamification to promote sustainable consumption and energy conservation behaviors has found that promoting competence and autonomy among users facilitates intrinsic (Wee and Choong, 2019) and identified (Mulcahy et al., 2020) forms of motivation, which are regarded as autonomous motivation (Ryan and Deci, 2000). Similarly, studies into the use of gamification to promote exercise have found that experiencing competence and autonomy increases users' motivation to continue playing the exercise game (Peng et al., 2012). Similarly, autonomy has been associated with autonomous motivation to use gamified 
exercise apps (Bitrián et al., 2020). Finally, research into work gamification has also found a positive correlation between the satisfaction of the needs for competence and autonomy and autonomous motivation (Buil et al., 2020; Mitchell et al., 2020). Based on these arguments, we hypothesize that:

H2a. Competence positively influences users' autonomous motivation to use gamified PFM apps.

H2b. Autonomy positively influences users' autonomous motivation to use gamified PFM apps.

To achieve a better understanding of the effects of gamified technologies, research should focus both on the motivation derived from interacting with gameful affordances and how this motivation enhances users' perceptions of the technologies (Buil et al., 2020).

The TAM (Davis, 1989) proposed that individuals' attitudes toward specific technologies are predicted by two key variables, perceived usefulness, and ease of use. Perceived usefulness relates to the user's belief that a system will boost his or her performance, while perceived ease of use refers to the user's belief that using a system will not require extra effort (Davis, 1989).

Previous research has shown that perceptions of ease of use and usefulness are influenced by users' motivations to use systems (e.g., Sun and Zhang, 2006; Buil et al., 2020). When users enjoy operating technology and find it entertaining and motivating, they tend to perceive it as easy to use (Venkatesh, 2000; Venkatesh et al., 2002; Yi and Hwang, 2003; Fagan et al., 2008; Roca and Gagné, 2008; Laumer et al., 2012) and to find it useful (Yi and Hwang, 2003; Roca and Gagné, 2008; Laumer et al., 2012). In the mobile banking context, previous research has reported that experiencing enjoyment promotes greater perceptions of ease of use (Koenig-Lewis et al., 2015; Rodrigues et al., 2016b, 
2016c; Santiniti et al., 2019) and usefulness (Koenig-Lewis et al., 2015; Santiniti et al., 2019) of the mobile technology. On the basis of these arguments, we propose that users who are autonomously motivated to use gamified PFM apps will perceive them as easy to use and useful. Hence, we propose the following hypotheses:

H3. Users' autonomous motivation to use gamified PFM apps positively influences their perceptions of (a) ease of use and (b) usefulness.

As previously mentioned, users' attitudes toward specific technologies are more favorable when they perceive them as easy to use and useful (Davis, 1989; Davis et al., 1989). The TAM also suggests that when users believe that technology is easy to use and requires minimum time and effort, they perceive it as effective and provides benefits. Therefore, the ease of use of a system also positively influences users' perceptions of its usefulness (e.g., Ong et al., 2004; Shih, 2004; Shang et al., 2005; Venkatesh, 2000).

In gamified contexts, Hamari and Koivisto (2015a) demonstrated that the usefulness of gamified apps is positively related to users' attitudes toward them. In the banking field, previous research has also found that the perceived ease of use and perceived usefulness of mobile banking apps create more favorable attitudes toward mobile banking (Lee, 2009; Akturan and Tezcan, 2012; Mohammadi, 2015; Giovanis et al., 2019). Similarly, when users perceive that using a mobile banking app is easy, they tend to perceive it to be useful (Lee, 2009; Karjaluoto et al., 2010; Akturan and Tezcan, 2012; Mohammadi, 2015; Rodrigues et al., 2016b, 2016c).

Early finance apps were based on manual information inputs provided by users, but the newest PFM apps are linked to users' accounts and bank cards and receive transaction data automatically. Therefore, the newest apps are easier to use, more useful, and 
efficient, as their users are not forced to perform unnecessary actions, and they do not rely on the users' memories, which saves them much time (Srivastava, 2020).

Based on these arguments we propose the following hypotheses:

H4a. Perceived ease of use positively influences users' attitudes toward gamified PFM apps.

H4b. Perceived usefulness positively influences users' attitudes toward gamified PFM apps.

H4c. Perceived ease of use positively influences perceived usefulness.

The TAM proposes that having a favorable attitude toward technology is the main determinant of behavioral intention to use the technology (Davis et al., 1989). Previous research has shown that when users have a positive attitude toward mobile apps, they are willing to continue using those apps and recommend them to others (Hamari and Koivisto, 2013, 2015b). Similarly, users' attitudes have been shown to be highly important factors in predicting the use of internet banking and mobile banking services (Lee, 2009; Akturan and Tezcan, 2012; Baptista and Oliveira, 2016; Muñoz-Leiva et al., 2017; Chauhan et al., 2019; Giovanis et al., 2019). In addition, it has been found that positive attitudes toward mobile applications may lower barriers to adoption (MuñozLeiva et al., 2017). Therefore, we hypothesize that:

H5. Users' attitudes toward gamified PFM apps positively influences their behavioral intention to use them. 


\section{Methodology}

\subsection{Data collection}

To estimate the minimum sample size, the program $G^{*}$ Power (version 3.1.9.7) was used (Faul et al., 2007). For an alpha of 0.05 , an effect size estimated of 0.15 , a power of $80 \%$ and a number of predictors of 2 (the highest number of predictors of a latent variable in the model), a total sample size of 68 would be required. However, to have a more consistent model, it is suggested to double or triple this amount (Ringle et al., 2014).

A sample of 208 users of the Mint app was recruited using the SurveyMonkey Audience service. The number of respondents was above the required sample size and is similar to that of previous studies that have explored the use of gamification in the finance industry (e.g., Rodriguez et al., 2016b, 2016c, 2017; Bayuk and Altobello, 2019).

The characteristics of the sample are presented in Table II. The Mint app, owned by the Intuit company, was selected because it is one of the most popular PFM apps in the U.S. (Business Insider, 2020). This gamified app provides its users with feedback by rating their achievements and sets up alerts in the form of reminders and notifications. In addition, the app allows users to set budgetary goals in different expense categories, track money movements, bills and expenses, and personalize some of the apps' aspects. Therefore, five motivational affordances/game elements (i.e., credit score, alerts, budgets, tracking, and personalization) were examined in the study.

[Table II here]

\subsection{Measurement instrument}

All the variables used in the study were adapted from relevant previous literature and measured through 7-point scales (see Appendix). Users' interactions with motivational affordances and their need for competence were measured following Xi and Hamari 
(2019). Their need for autonomy was measured using items from Xi and Hamari (2019) and Standage et al. (2005). Autonomous motivation was measured following Guay et al. (2000). Perceived ease of use and perceived usefulness were both measured based on Davis (1989), while attitude was measured following Taylor and Todd (1995). Finally, items from Venkatesh et al. (2012) were used to measure behavioral intention.

\subsection{Common method bias assessment}

As the data were collected through a self-reported survey, some procedural and statistical methods were followed to ensure that common method bias was not an issue in this study (Podsakoff et al., 2003). Regarding the procedural methods, the participants freely agreed to participate in the study, and their anonymity was guaranteed. In addition, in the online survey design, the dependent and independent variables were included on different pages of the survey to prevent the respondents from identifying cause-effect relationships among the constructs. As to the statistical methods, common method bias was assessed through a full collinearity test based on the variance inflation factors (VIF). The VIF values ranged from 1.000 to 1.841 (all lower than 3.3). Thus, there is no evidence in this research to suggest the presence of a common-method bias (Kock, 2015).

\section{Results}

As the proposed model includes formative and reflective constructs, partial least squares (PLS) structural equation modeling with SmartPLS 3.0 was used to test the model (Chin, 2010; Hair et al., 2011; Ringle et al., 2015; Shmueli et al., 2016). PLS simultaneously assesses the measurement and the structural model. These two steps are described next. 


\subsection{Measurement model analysis}

First, the formative measurement model for the first-order dimensions was analyzed (Table III). User interaction with the app's motivational affordances was conceptualized as a second-order formative construct with five first-order factors: credit score, alerts, budgets, tracking, and personalization. Following Xi and Hamari (2019), each factor was measured formatively by two indicators, the frequency and the importance of the interactions. External validity was analyzed by assessing the indicators' weights and loadings. Although the weights of the indicators should ideally be statistically significant, Hair et al. (2017) argued that indicators with non-significant weights but with high loadings ( $>0.5)$ should be retained, as they contribute to the construct. Thus, the external validity of the model was shown to be acceptable. Thereafter, collinearity was evaluated through the VIF values. The values ranged from 1.902 to 2.952 , below the threshold of 5 , which indicates an absence of collinearity problems (Hair et al., 2011).

\section{[Table III here]}

Then, the two-stage approach suggested by Hair et al. (2018) was used to assess the second-order formative construct. As Table IV shows, the external validity was assessed through the indicators' weights and loadings. Following Hair et al. (2017), the item "personalization" was removed, as it had neither statistically significant weights nor high loadings. The model was then re-estimated, and the external validity of the remainder of the indicators was shown to be acceptable (Hair et al., 2017). In addition, the model had no collinearity problems, as the VIF values were all below 5 (Hair et al., 2011).

\section{[Table IV here]}

Second, the reflective measurement model was analyzed following Hair et al.'s (2017) criteria (see Table V). The results show that the Cronbach's alpha and composite 
reliability (CR) of all constructs were greater than 0.7 , confirming internal consistency reliability. Then, the individual item reliability for all factor loadings was confirmed, as they were all greater than 0.60 and statistically significant at $1 \%$ (Carmines and Zeller, 1979). Convergent validity was also confirmed as the average variance extracted (AVE) values were above 0.5 (Fornell and Larcker, 1981). Finally, discriminant validity was examined using three tests (Hair et al., 2017): cross-loadings, the Fornell-Larcker criterion, and the HTMT ratios. First, we checked that all indicators' outer loadings on the associated construct were greater than any of their cross-loadings on other constructs. Next, we confirmed that the square roots of the AVEs of each construct were greater than the inter-construct correlations (Fornell and Larcker, 1981) (see Table VI). Third, we confirmed that all HTMT values were below the threshold of 0.90 and that the bootstrap confidence interval did not contain the value 1 (see Table VII).

[Table V here]

[Table VI here]

[Table VII here]

\subsection{Structural model analysis}

The next section of the analysis evaluated the statistical significance of the standardized paths through a bootstrapping process, with 5,000 subsamples. It was shown that the model explains $31.5 \%$ of the variance of competence need satisfaction, $27.3 \%$ of autonomy need satisfaction, $47.4 \%$ of the user's autonomous motivation, $28.9 \%$ of perceived ease of use, $53.4 \%$ of perceived usefulness, $54.9 \%$ of the user's attitude and $62.2 \%$ of behavioral intention. In addition, as the $\mathrm{Q}^{2}$ values for the dependent variables were positive, the model has predictive relevance (Table V). 
The results obtained from the structural model analysis are presented in Table VIII. As can be seen, all the proposed hypotheses are supported. First, interaction with motivational affordances in the gamified PFM app facilitates the satisfaction of the needs for competence $(\beta=0.56 ; \mathrm{t}=10.55)$ and autonomy $(\beta=0.52 ; \mathrm{t}=8.96)$, supporting H1a and $\mathrm{H} 1 \mathrm{~b}$, respectively. Both the satisfaction of the need for competence $(\beta=0.46 ; \mathrm{t}=$ 5.91) and for autonomy $(\beta=0.32 ; \mathrm{t}=4.61)$ promote users' autonomous motivation to use the gamified PFM app. Therefore, $\mathrm{H} 2 \mathrm{a}$ and $\mathrm{H} 2 \mathrm{~b}$ are supported. In accordance with our predictions, autonomous motivation is positively related to the perceived ease of use $(\beta=$ $0.53 ; \mathrm{t}=9.11)$ and the perceived usefulness $(\beta=0.33 ; \mathrm{t}=4.16)$ of the gamified PFM app, which supports $\mathrm{H} 3 \mathrm{a}$ and $\mathrm{H} 3 \mathrm{~b}$, respectively. In addition, perceived ease of use $(\beta=0.36$; $\mathrm{t}$ $=4.29)$ and perceived usefulness $(\beta=0.44 ; \mathrm{t}=5.59)$ are positively associated with users' attitudes toward the gamified PFM app, supporting H4a and H4b, respectively. Similarly, perceived ease of use influences perceived usefulness $(\beta=0.49 ; \mathrm{t}=6.56)$, supporting H4c. Finally, users' attitudes toward the gamified PFM app positively predict their behavioral intention to use the app $(\beta=0.60 ; \mathrm{t}=11.30)$. Thus, H5 is supported.

Regarding the control variables, the results showed that the frequency of use of the gamified PFM app positively affected users' behavioral intention to use it $(\beta=0.41 ; \mathrm{t}=$ 7.95).

[Table VIII here]

\section{Discussion}

PFM apps have recently gained popularity among users. To improve users' experiences and increase their motivation to use PFM apps, most have been gamified. However, there has been little research analyzing the effect of users' interactions with gameful 
affordances on their motivation to use the apps and their adoption. To bridge this gap, this study combined SDT and the TAM and simultaneously analyzed the influence of the motivational factors of perceived competence, perceived autonomy, and autonomous motivation, and the technology acceptance factors perceived ease of use and perceived usefulness, on users' attitude toward gamified PFM apps, and their behavioral intention to use them.

The results of this study provide support for the use of gamification in PFM apps. In particular, this study showed that the users' interactions with the motivational affordances embedded in PFM apps (e.g., budgets, tracking, credit scores, alerts) make them feel more competent and autonomous. The impact of various motivational affordances on competence and autonomy need satisfaction has been proven in various contexts, such as exercise (Peng et al., 2012), education (van Roy and Zaman, 2019), information systems (Suh et al., 2018), and energy conservation (Wee and Choong, 2019). However, this issue is still under debate. Other studies in contexts such as online simulations (Sailer et al., 2017), online brand communities (Xi and Hamari, 2019), and exercise apps (Bitrián et $a l ., 2020$ ) have found that the effect of some game elements on competence, autonomy, or even both, are nonsignificant. Nonetheless, our findings add weight to the argument that motivational affordances have a positive influence on the satisfaction of these needs. In addition, in line with previous research drawing on SDT (Bitrián et al., 2020; Buil et al., 2020; Mitchell et al., 2020), this study proved that when users feel competent and self-determined as a result of using gamified PFM apps, they are autonomously motivated to use them. The study also demonstrated that users' autonomous motivation to use gamified PFM apps leads them to perceive the apps as useful and easy to use. This finding contributes to the current debate about the direction of the relationship between motivation and perceived ease of use (Sun and Zhang, 2006) by showing that the 
motivation to use PFM apps makes users regard them as more useful, and easy to use. In line with the TAM, this research demonstrates that perceiving the app as easy to use promotes the user's perception that the app is useful (e.g., Lee, 2009; Karjaluoto et al., 2010; Akturan and Tezcan, 2012). Moreover, as shown in previous studies (e.g., Lee, 2009; Akturan and Tezcan, 2012; Giovanis et al., 2019), this research demonstrates that users' perceptions of PFM apps' usefulness and ease of use promote favorable attitudes toward them. Similarly, it was demonstrated that a positive attitude leads to a higher behavioral intention to use the gamified PFM app.

\subsection{Theoretical implications}

This study makes several theoretical contributions to the gamification literature in general, and to research into PFM apps in particular. First, compared to other contexts, relatively few studies have focused on the use of gamification in the finance domain. Thus, this study responds to the recent call for academic research into the effects of gamified PFM apps (Bayuk and Altobello, 2019). In addition, as most previous research into app gamification in the finance/banking sector has not focused on the user's interactions with motivational affordances, this study contributes to the literature by providing new insights into the use of PFM apps and how these user-game element interactions affect their users' motivation and their use of the apps. Second, taking into account the lack of theoretical foundations in the gamification literature reported by previous research (Seaborn and Fels, 2015; Koivisto and Hamari, 2019), this study contributes to the existing body of research by proposing and testing a model combining SDT, one of the major theories explaining human motivation, and the TAM, which focuses on the factors that affect new technology acceptance, and which has been used successfully to analyze finance apps (Tam and Oliveira, 2016). In fact, to the best of the authors' knowledge, the present study is the first attempt to combine both theories in this 
context, providing a better explanation of the antecedents of users' attitude toward gamified PFM apps. Finally, by conducting an empirical study in a real gamified context using previously validated measures, this work overcomes some of the methodological shortcomings reported in previous studies, such as the use of small samples and nonvalidated measures, and the use of overly descriptive approaches (Hamari et al., 2014; Koivisto and Hamari, 2019; Rapp et al., 2019), and responds to the call for more empirical research into the acceptance of gamified PFM apps in real-life scenarios (Rodrigues et al., 2016b, 2017).

\subsection{Managerial implications}

This study also provides a number of practical implications for PFM app managers and designers, especially for fintech companies and banks seeking to enhance the user experience. First, the design of apps should help their users experience autonomous motivation and, thus, their integrated gamified elements should allow them to feel competent and self-determined. In addition to merely storing financial information about users' cards and accounts, it would be interesting if PFM apps could offer their users the possibility to set personal goals regarding their finances, such as fixing saving objectives for the family's summer holidays, or to buy a new car. This would offer users a feeling of self-determination, as they would perceive a sense of autonomy through being able to

customize their app experience. Similarly, this would help to promote feelings of competence, as setting and accomplishing these financial goals would give users a sense of purpose. In addition, providing functionality that will allow users to create specific budgets for the categories that are more important to them personally (e.g., household bills, food, leisure), and let them fix maximum limits for those categories they want to cut (e.g., fashion, technology items), will help them feel more autonomous, and permit them to flexibly customize their experiences. Moreover, to motivate users to achieve their 
financial goals, PFM apps should offer real-time money tracking, and provide visual information in the form of performance graphs/progress bars, so they can see how successful they are in meeting their goals. This will help them feel more competent in the use of the app, and to feel purposeful. Similarly, keeping users informed about specific events (e.g., expenditure, account balances, upcoming bills) with in-app alerts and notifications, and rewarding them with scores/virtual badges for their achievements, will also promote feelings of competence and autonomy, and make them more motivated to use the app. In addition, to promote favorable attitudes toward PFM apps they should be designed such that users find them easy to use and useful. Unlike mobile banking apps designed to manage the money users have in one specific branch, PFM apps compile information from different financial sources. Thus, users should be able to link all their accounts and bank cards within the app, so that it automatically receives all the necessary information. The alerts and notifications provided by the app might also enhance perceptions of usefulness.

\subsection{Limitations and future research}

Despite its substantial contributions, this study has some limitations that offer avenues for future research. First, only one specific PFM app was analyzed. Thus, it would be interesting to replicate this study using other PFM apps. Second, while this study has shown how gamification can increase behavioral intention to use PFM apps, variables related to positive financial behaviors were not considered. Hence, future research might analyze if applying gamification to PFM apps increases their users' financial well-being and financial literacy. In addition, the data was collected at one specific time. Therefore, it would be interesting to analyze the effectiveness of gamification within a longitudinal framework, as this might provide insights into probable causation and long-term effects. 


\section{References}

Akturan, U. and Tezcan, N. (2012), "Mobile banking adoption of the youth market”, Marketing Intelligence and Planning, Vol. 30 No. 4, pp. 444-459.

App Annie (2020), "The State of Mobile in 2020", available at: https://www.appannie.com/en/insights/market-data/2020-mobile-finance-apps-

report/

AppsFlyer (2020), “Finance Apps See 90\% Increase in Install Market Share Worldwide According to AppsFlyer", available at: https://www.appsflyer.com/pr/finance-appssee-90-increase-in-install-market-share-worldwide-according-to-appsflyer/

Baptista, G. and Oliveira, T. (2016), “A weight and a meta-analysis on mobile banking acceptance research", Computers in Human Behavior, Vol. 63, pp. 480-489.

Baptista, G. and Oliveira, T. (2017), "Why so serious? Gamification impact in the acceptance of mobile banking services", Internet Research, Vol. 27 No. 1, pp. 118139.

Bayuk, J. and Altobello, S. A. (2019), “Can gamification improve financial behavior? The moderating role of app expertise", International Journal of Bank Marketing, Vol. 37 No. 4, pp. 951-975.

Bitrián, P., Buil, I. and Catalán, S. (2020), "Gamification in sport apps: the determinants of users' motivation", European Journal of Management and Business Economics, Vol. 29 No. 3, pp. 365-381.

Buil, I., Catalán, S. and Martínez, E. (2020), “Understanding applicants' reactions to gamified recruitment”, Journal of Business Research, Vol. 110, pp. 41-50.

Business Insider (2020), "These are the top fintech companies and startups in 2021", available at: https://www.businessinsider.com/fintech-companies-startups 
Carmines, E. G. and Zeller, R. A. (1979), Reliability and validity assessment, Newbury Park, CA (US): Sage Publications.

Chauhan, V., Yadav, R. and Choudhary, V. (2019), “Analyzing the impact of consumer innovativeness and perceived risk in internet banking adoption: A study of Indian consumers", International Journal of Bank Marketing, Vol. 37 No. 1, pp. 323-339.

Chin, W.W. (2010), How to write up and report PLS analyses, In Handbook of Partial Least Squares (pp. 655-690), Springer Heidelberg, Berlin.

Davis, F. D. (1989), "Perceived usefulness, perceived ease of use, and user acceptance of information technology”, MIS Quarterly, pp. 319-340.

Davis, F. D., Bagozzi, R. P. and Warshaw, P. R. (1989), "User acceptance of computer technology: a comparison of two theoretical models", Management Science, Vol. 35 No. 8, pp. 982-1003.

de Charms, R. (1968), Personal Causation, New York: Academic.

Deci, E. (1975), Intrinsic motivation, New York: Plenum Press.

Deci, E. and Ryan, R. (2000), “The 'what' and 'why' of goal pursuits: Human needs and the self-determination of behavior", Psychological Inquiry, Vol. 11, pp. 227-268.

Deci, E. and Ryan, R. (2015), Self-Determination Theory. International Encyclopedia of the Social and Behavioral Sciences, 2nd edition, Vol. 21, pp. 486-491.

Deci, E., Ryan, R. and Williams, G. (1996), "Need satisfaction and the self-regulation of learning”, Learning and Individual Differences, Vol. 8 No. 3, pp. 165-183.

Deterding, S., Dixon, D., Khaled, R. and Nacke, L. (2011), "From game design elements to gamefulness: Defining “gamification"”, MindTrek 2011.

Fagan, M. H., Neill, S. and Wooldridge, B. R. (2008), "Exploring the intention to use computers: An empirical investigation of the role of intrinsic motivation, extrinsic 
motivation, and perceived ease of use", Journal of Computer Information Systems, Vol. 48 No. 3, pp. 31-37.

Faul, F., Erdfelder, E., Lang, A.-G. and Buchner, A. (2007), "G*Power 3: A flexible statistical power analysis program for the social, behavioral, and biomedical sciences", Behavior Research Methods, 39, 175-191.

Fornell, C. and Larcker, D. F. (1981), "Evaluating structural equation models with unobservable variables and measurement error", Journal of Marketing Research, Vol. 18 No. 1, pp. 39-50.

Gagné, M., Forest, J., Vansteenkiste, M., Crevier-Braud, L., van den Broeck, A., Aspeli, A., ... Westbye, C. (2015), "The Multidimensional Work Motivation Scale: Validation evidence in seven languages and nine countries", European Journal of Work and Organizational Psychology, Vol. 24, pp. 178-196.

Garzaro, D.M., Varotto, L.F. and Pedro, S.d.C. (2021), "Internet and mobile banking: the role of engagement and experience on satisfaction and loyalty", International Journal of Bank Marketing, Vol. 39 No. 1, pp. 1-23.

Giovanis, A., Athanasopoulou, P., Assimakopoulos, C. and Sarmaniotis, C. (2019), “Adoption of mobile banking services", International Journal of Bank Marketing, Vol. 37 No. 5, pp. 1165-1189.

Guay, F., Vallerand, R. J. and Blanchard, C. (2000), "On the assessment of situational intrinsic and extrinsic motivation: The Situational Motivation Scale (SIMS)", Motivation and Emotion, Vol. 24 No. 3, pp. 175-213.

Hair, J.F., Hult, G.T., Ringle, C.M. and Sarstedt, M. (2017), A Primer on Partial Least Squares Structural Equation Modeling (PLS-SEM), Second Edition, SAGE, Los Angeles. 
Hair, J.F., Ringle, C.M. and Sarstedt, M. (2011), "PLS-SEM: Indeed a siler bullet", Journal of Marketing Theory and Practice, Vol. 19 No. 2, pp. 139-152.

Hair, J.F., Sarstedt, M., Ringle, C.M. and Gundergan, P. (2018), Advanced Issues in Partial Least Squares Structural Equation Modeling, SAGE, Los Angeles.

Hamari, J. and Koivisto, J. (2013), Social motivations to use gamification: An empirical study of gamifying exercise, In ECIS (Vol. 105).

Hamari, J. and Koivisto, J. (2015a), "Why do people use gamification services?”, International Journal of Information Management, Vol. 35 No. 4, pp. $419-431$.

Hamari, J. and Koivisto, J. (2015b), "Working out for likes": An empirical study on social influence in exercise gamification", Computers in Human Behavior, Vol. 50, pp. 333-347.

Hamari, J., Koivisto, J. and Sarsa, H. (2014), “Does Gamification Work? - A Literature Review of Empirical Studies on Gamification", Proceedings of the HICSS 2013 Conference.Washington, DC.

Heung, V. C. and Gu, T. (2012), "Influence of restaurant atmospherics on patron satisfaction and behavioral intentions", International Journal of Hospitality Management, Vol. 31 No. 4, pp. 1167-1177.

Hofacker, C. F., De Ruyter, K., Lurie, N. H., Manchanda, P. and Donaldson, J. (2016), "Gamification and mobile marketing effectiveness", Journal of Interactive Marketing, Vol. 34, pp. 25-36.

Huotari, K. and Hamari, J. (2017), “A definition for gamification: anchoring gamification in the service marketing literature", Electronic Markets, Vol. 27 No. 1, pp. 21-31.

Huston, S. J. (2010), “Measuring financial literacy”, Journal of Consumer Affairs, Vol. 44 No. 2, pp. 296-316. 
Jun, M. and Palacio, S. (2016), "Examining the key dimensions of mobile banking service quality: and exploratory study", International Journal of Bank Marketing, Vol. 34 No. 3, pp. 307-326.

Karjaluoto, H., Riquelme, H. E. and Rios, R. E. (2010), “The moderating effect of gender in the adoption of mobile banking", International Journal of Bank Marketing, Vol. 28 No. 5, pp. 328-341.

Karjaluoto, H., Shaikh, A. A., Saarijärvi, H. and Saraniemi, S. (2019), "How perceived value drives the use of mobile financial services apps", International Journal of Information Management, Vol. 47, pp. 252-261.

Kasurinen, J. and Knutas, A. (2018), "Publication trends in gamification: A systematic mapping study”, Computer Science Review, Vol. 27, pp. 33-44.

Kim, K., Schmierbach, M. G., Chung, M. Y., Fraustino, J. D., Dardis, F. and Ahern, L. (2015), "Is it a sense of autonomy, control, or attachment? Exploring the effects of in-game customization on game enjoyment", Computers in Human Behavior, Vol. 48, pp. 695-705.

Kock, N. (2015), "Common method bias in PLS-SEM: a full collinearity assessment approach", International Journal of e-Collaboration, Vol. 11 No. 4, pp. 1-10.

Koenig-Lewis, N., Marquet, M., Palmer, A. and Zhao, A. L. (2015), "Enjoyment and social influence: predicting mobile payment adoption", The Service Industries Journal, Vol. 35 No. 10, pp. 537-554.

Koivisto, J. and Hamari, J. (2019), "The rise of motivational information systems: A review of gamification research", International Journal of Information Management, Vol. 45, pp. 191-210. 
Komulainen, H. and Saraniemi, S. (2019), "Customer centricity in mobile banking: a customer experience perspective”, International Journal of Bank Marketing, Vol. 37 No. 5, pp. 1082-1102.

Laumer, S., Eckhardt, A. and Weitzel, T. (2012), "Online gaming to find a new job: Examining job seekers' intention to use serious games as a self-assessment tool”, Zeitschrift für Personalforschung, Vol. 26, pp. 218-240.

Lee, M. C. (2009), "Factors influencing the adoption of internet banking: An integration of TAM and TPB with perceived risk and perceived benefit", Electronic Commerce Research and Applications, Vol. 8 No. 3, pp. 130-141.

Liu, X., Zhang, Z., Law, R. and Zhang, Z. (2019), "Posting reviews on OTAs: Motives, rewards and effort”, Tourism Management, Vol. 70, pp. 230-237.

Mekler, E. D., Brühlmann, F., Tuch, A. N. and Opwis, K. (2017), "Towards understanding the effects of individual gamification elements on intrinsic motivation and performance", Computers in Human Behavior, Vol. 71, pp. 525-534.

Mitchell, R., Schuster, L. and Jin, H. S. (2020), "Gamification and the impact of extrinsic motivation on needs satisfaction: Making work fun?”, Journal of Business Research, Vol. 106, pp. 323-330.

Mohammadi, H. (2015), “A study of mobile banking usage in Iran”, International Journal of Bank Marketing, Vol. 33 No. 6, pp. 733-759.

Mulcahy, R., Russell-Bennett, R. and Iacobucci, D. (2020), “Designing gamified apps for sustainable consumption: A field study", Journal of Business Research, Vol. 106, pp. 377-387.

Muñoz-Leiva, F., Climent-Climent, S. and Liébana-Cabanillas, F. (2017), "Determinants of intention to use the mobile banking apps: An extension of the classic TAM model”, Spanish Journal of Marketing-ESIC, Vol. 21 No. 1, pp. 25-38. 
Nasirzadeh, E. and Fathian, M. (2020), "Investigating the Effect of Gamification Elements on Bank Customers to Personalize Gamified Systems”, International Journal of Human-Computer Studies, pp. 102469.

Ong, C. S., Lai, J. Y. and Wang, Y. S. (2004), "Factors affecting engineers' acceptance of asynchronous e-learning systems in high-tech companies", Information \& Management, Vol. 41 No. 6, pp. 795-804.

Peng, W., Lin, J., Pfeiffer, K. and Winn, B. (2012), "Need satisfaction supportive game features as motivational determinants: An experimental study of a selfdetermination theory guided exergame", Media Psychology, Vol. 15, pp. 175-196.

Podsakoff, P. M., MacKenzie, S. B., Lee, J. Y. and Podsakoff, N. P. (2003), “Common method biases in behavioral research: a critical review of the literature and recommended remedies", Journal of Applied Psychology, Vol. 88 No. 5, pp. 879903.

QYResearch (2019), “Global Personal Finance Apps Market Size, Status and Forecast 2018-2025", available at: https://www.marketresearch.com/QYResearch-Groupv3531/Global-Personal-Financial-Management-Tools-12732938/

Rahi, S. and Ghani, M.A. (2018), "The role of UTAUT, DOI, perceived technology security and game elements in internet banking adoption”, World Journal of Science, Technology and Sustainable Development, Vol. 15 No. 4, pp. 338-356.

Rahi, S. and Ghani, M. A. (2019), “Does gamified elements influence on user's intention to adopt and intention to recommend internet banking?", The International Journal of Information and Learning Technology, Vol. 36 No. 1, pp. 2-20.

Rapp, A., Hopfgartner, F., Hamari, J., Linehan, C. and Cena, F. (2019), “Strengthening gamification studies: Current trends and future opportunities of gamification research”, International Journal of Human Computer Studies, Vol. 127, pp. 1-6. 
Ringle, C., Da Silva, D. and Bido, D. (2014), "Structural equation modeling with the SmartPLS”, Brazilian Journal of Marketing, Vol. 13 No. 2, pp. 56-73.

Ringle, C., Wende, S. and Becker, J. (2015). SmartPLS 3. SmartPLS GmbH, Bönningstedt.

Roca, J. and Gagné, M. (2008), "Understanding e-learning continuance intention in the workplace: A self-determination theory perspective", Computers in Human Behavior, Vol. 24, pp. 1585-1604.

Rodrigues, L. F., Costa, C. J. and Oliveira, A. (2016a), “Gamification: A framework for designing software in e-banking", Computers in Human behavior, Vol. 62, pp. 620634.

Rodrigues, L. F., Costa, C. J. and Oliveira, A. (2017), "How does the web game design influence the behavior of e-banking users?", Computers in Human Behavior, Vol. 74, pp. 163-174.

Rodrigues, L. F., Oliveira, A. and Costa, C. J. (2016b), "Does ease-of-use contributes to the perception of enjoyment? A case of gamification in e-banking", Computers in Human Behavior, Vol. 61, pp. 114-126.

Rodrigues, L. F., Oliveira, A. and Costa, C. J. (2016c), "Playing seriously-How gamification and social cues influence bank customers to use gamified e-business applications", Computers in Human Behavior, Vol. 63, pp. 392-407.

Ryan, R. M. and Deci, E. L. (2000), "Self-determination theory and the facilitation of intrinsic motivation, social development, and well-being”, American Psychologist, Vol. 55, pp. 68-78.

Ryan, R., Rigby, C. and Przybylski, A. (2006), "The motivational pull of video games: A selfdetermination theory approach", Motivation and Emotion, Vol. 30 No. 4, pp. $344-360$. 
Sailer, M., Hense, J., Mandl, J. and Klevers, M. (2013), "Psychological perspectives on motivation through gamification", Interaction Design and Architecture Journal, Vol. 19, pp. 28-37.

Sailer, M., Hense, J., Mayr, S. and Mandl, H. (2017), "How gamification motivates: An experimental study of the effects of specific game design elements on psychological need satisfaction", Computers in Human Behavior, Vol. 69, pp. 371-380.

Santini, F. D. O., Ladeira, W. J., Sampaio, C. H., Perin, M. G. and Dolci, P. C. (2019), "A meta-analytical study of technological acceptance in banking contexts", International Journal of Bank Marketing, Vol. 37 No. 3, pp. 755-774.

Seaborn, K. and Fels, D. (2015), "Gamification in theory and action: A survey", International Journal of Human-Computer Studies, Vol. 74, pp. 14-31.

Shang, R. A., Chen, Y. C. and Shen, L. (2005), "Extrinsic versus intrinsic motivations for consumers to shop on-line", Information \& Management, Vol. 42 No. 3, pp. 401413.

Shih, H. P. (2004), "Extended technology acceptance model of Internet utilization behavior", Information \& Management, Vol. 41 No. 6, pp. 719-729.

Shmueli, G., Ray, S., Estrada, J.M.V. and Chatla, S.B. (2016), "The elephant in the room: Predictive performance of PLS models", Journal of Business Research, Vol. 69 No. 10, pp. $4552-4564$.

Souiden, N., Ladhari, R. and Chaouali, W. (2021), "Mobile banking adoption: a systematic review”, International Journal of Bank Marketing, Vol. 39 No. 2, pp. 214241.

Srivastava, S. (2020), "How to build an effective personal finance application", Appinventiv.com, available at: https://appinventiv.com/blog/how-to-build-personalfinance-app/ 
Standage, M., Duda, J.L. and Ntoumanis, N. (2005), "A test of self-determination theory in school physical education", British Journal of Educational Psychology, Vol. 75 No. 3, pp. 411-433.

Suh, A., Wagner, C. and Liu, L. (2018), "Enhancing user engagement through gamification", Journal of Computer Information Systems, Vol. 58 No. 3, pp. 204213.

Sun, H. and Zhang, P. (2006), "Causal relationships between perceived enjoyment and perceived ease of use: An alternative approach", Journal of the Association for Information Systems, Vol. 7 No. 9, pp. 618-645.

Tam, C. and Oliveira, T. (2016), "Performance impact of mobile banking: using the tasktechnology fit (TTF) approach", International Journal of Bank Marketing, Vol. 34 No. 4, pp. 434-457.

Taylor, S. and Todd, P. A. (1995), “Understanding information technology usage: A test of competing models", Information Systems Research, Vol. 6 No. 2, pp. 144-176.

Tobon, S., Ruiz-Alba, J.L. and García-Madariaga, J. (2020), “Gamification and online consumer decisions: Is the game over?", Decision Support Systems, Vol. 128, pp. 113167.

Tu, R., Hsieh, P. and Feng, W. (2019), "Walking for fun or for "likes"? The impacts of different gamification orientations of fitness apps on consumers' physical activities", Sport Management Review, Vol. 22 No. 5, pp. 682-693.

van Roy, R. and Zaman, B. (2019), "Unravelling the ambivalent motivational power of gamification: A basic psychological needs perspective", International Journal of Human-Computer Studies, Vol. 127, pp. 38-50. 
Venkatesh, V. (2000), "Determinants of perceived ease of use: Integrating control, intrinsic motivation, and emotion into the technology acceptance model”, Information Systems Research, Vol. 11 No. 4, pp. 342-365.

Venkatesh, V., Speier, C. and Morris, M. G. (2002), "User acceptance enablers in individual decision making about technology: Toward an integrated model”, Decision Sciences, Vol. 33 No. 2, pp. 297-316.

Venkatesh, V., Thong, J. Y. and Xu, X. (2012), "Consumer acceptance and use of information technology: extending the unified theory of acceptance and use of technology", MIS Quarterly, pp. 157-178.

Wang, A. I. and Tahir, R. (2020), "The effect of using Kahoot! for learning-A literature review", Computers \& Education, Vol. 149, pp. 103818.

Wee, S. C. and Choong, W. W. (2019), "Gamification: Predicting the effectiveness of variety game design elements to intrinsically motivate users' energy conservation behavior", Journal of Environmental Management, Vol. 233, pp. 97-106.

Werbach, K. and Hunter, D. (2012), For the Win: How game thinking can revolutionalize your business, Wharton: Digital Press.

White, R. W. (1959), "Motivation reconsidered: The concept of competence", Psychological Review, Vol. 66 No. 5, pp. 297-233.

Wünderlich, N. V., Gustafsson, A., Hamari, J., Parvinen, P. and Haff, A. (2020), “The great game of business: Advancing knowledge on gamification in business contexts", Journal of Business Research, Vol. 106, pp. 273-276.

Xi, N. and Hamari, J. (2019), "Does gamification satisfy needs? A study on the relationship between gamification features and intrinsic need satisfaction", International Journal of Information Management, Vol. 46, pp. 210-221. 
Yi, M. and Hwang, Y. (2003), "Predicting the use of web-based information systems: Selfefficacy, enjoyment, learning goal orientation, and the technology acceptance model”, International Journal of Human-Computer Studies, Vol. 59, pp. 431-449. 
Table I. Summary of empirical studies exploring gamification in the finance sector

\begin{tabular}{|c|c|c|c|c|c|}
\hline Reference & Aim & $\begin{array}{l}\text { Type / } \\
\text { Research } \\
\text { design }\end{array}$ & Context & Variables studied & Key findings \\
\hline $\begin{array}{l}\text { Rodrigues } \\
\text { et al. } \\
\text { (2016a) }\end{array}$ & $\begin{array}{l}\text { To develop a framework for } \\
\text { software gamified in e- } \\
\text { banking }\end{array}$ & $\begin{array}{l}\text { Empirical / } \\
\text { Qualitative } \\
\text { (discussion } \\
\text { groups) }\end{array}$ & e-banking & $\begin{array}{l}\text { Users' perceptions about the software } \\
\text { features, functionalities, and } \\
\text { characteristics, in five gamification } \\
\text { cases }\end{array}$ & $\begin{array}{l}\text { Based on users' designs preferences, ten } \\
\text { dimensions organized into two categories are } \\
\text { identified: characteristics (design, appearance, } \\
\text { functionality, rules, and objectives) and elements } \\
\text { (game, product, security, process, and } \\
\text { information) }\end{array}$ \\
\hline $\begin{array}{l}\text { Rodrigues } \\
\text { et al. } \\
(2016 \mathrm{~b})\end{array}$ & $\begin{array}{l}\text { To investigate how ease-of- } \\
\text { use and enjoyment influence } \\
\text { customers' use of e-banking } \\
\text { with a gamified business } \\
\text { software }\end{array}$ & $\begin{array}{l}\text { Empirical / } \\
\text { Quantitative } \\
\text { (survey) }\end{array}$ & e-banking & $\begin{array}{l}\text { Socialness, ease-of-use, enjoyment, } \\
\text { usefulness and intention to use }\end{array}$ & $\begin{array}{l}\text { Ease-of-use and enjoyment are interrelated, and } \\
\text { both have influence in e-banking usage; } \\
\text { socialness influences the user perceptions of } \\
\text { enjoyment and usefulness }\end{array}$ \\
\hline $\begin{array}{l}\text { Rodrigues } \\
\text { et al. } \\
(2016 \mathrm{c})\end{array}$ & $\begin{array}{l}\text { To identify the main } \\
\text { variables that influence bank } \\
\text { customers' use of gamified } \\
\text { e-banking applications }\end{array}$ & $\begin{array}{l}\text { Empirical / } \\
\text { Quantitative } \\
\text { (survey) }\end{array}$ & e-banking & $\begin{array}{l}\text { Gamification, socialness, ease-of-use, } \\
\text { enjoyment, usefulness, intention to use } \\
\text { and business impact }\end{array}$ & $\begin{array}{l}\text { Gamification improves customers' perceptions of } \\
\text { social interaction, which, in turn, influence } \\
\text { customers' intention to use the gamified } \\
\text { application }\end{array}$ \\
\hline $\begin{array}{l}\text { Rodrigues } \\
\text { et al. } \\
(2017)\end{array}$ & $\begin{array}{l}\text { To investigate how game } \\
\text { design integrated in a } \\
\text { banking website influences } \\
\text { customers' intention to use } \\
\text { e-banking }\end{array}$ & $\begin{array}{l}\text { Empirical / } \\
\text { Quantitative } \\
\text { (survey) }\end{array}$ & e-banking & $\begin{array}{l}\text { Gamification, ease-of-use, information, } \\
\text { web design, web characteristics and } \\
\text { intention to use }\end{array}$ & $\begin{array}{l}\text { Gamification has a significant influence on the } \\
\text { perceptions of ease of use, the web design, } \\
\text { information, webpage characteristics and the } \\
\text { intention to use e-banking }\end{array}$ \\
\hline
\end{tabular}




\begin{tabular}{|c|c|c|c|c|c|}
\hline Reference & Aim & $\begin{array}{l}\text { Type / } \\
\text { Research } \\
\text { design }\end{array}$ & Context & Variables studied & Key findings \\
\hline $\begin{array}{l}\text { Baptista } \\
\text { and } \\
\text { Oliveira } \\
(2017)\end{array}$ & $\begin{array}{l}\text { To identify the impact of } \\
\text { game mechanics and game } \\
\text { design techniques in the } \\
\text { acceptance of mobile } \\
\text { banking services }\end{array}$ & $\begin{array}{l}\text { Empirical / } \\
\text { Quantitative } \\
\text { (survey) }\end{array}$ & $\begin{array}{l}\text { Mobile } \\
\text { banking }\end{array}$ & $\begin{array}{l}\text { Performance expectancy, effort } \\
\text { expectancy, social influence, } \\
\text { facilitating conditions, hedonic } \\
\text { motivation, price value, habit, } \\
\text { gamification, behavioral intention and } \\
\text { use behavior } \\
\text { Age and gender (moderators) }\end{array}$ & $\begin{array}{l}\text { Gamification positively relates to intention to use } \\
\text { mobile banking services Performance expectation, } \\
\text { effort expectancy, social influence, hedonic } \\
\text { motivation, price value and habit have a positive } \\
\text { influence on behavioral intention. Facilitating } \\
\text { conditions, habit and behavioral intention have a } \\
\text { positive influence on use behavior }\end{array}$ \\
\hline $\begin{array}{l}\text { Rahi and } \\
\text { Ghani } \\
(2018)\end{array}$ & $\begin{array}{l}\text { To examine factors } \\
\text { influencing the adoption of } \\
\text { internet banking }\end{array}$ & $\begin{array}{l}\text { Empirical / } \\
\text { Quantitative } \\
\text { (survey) }\end{array}$ & $\begin{array}{l}\text { Internet } \\
\text { banking }\end{array}$ & $\begin{array}{l}\text { Performance expectancy, effort } \\
\text { expectancy, innovativeness, } \\
\text { compatibility, intention to adopt internet } \\
\text { banking and intention to recommend in } \\
\text { social networks } \\
\text { Gamification (moderator) }\end{array}$ & $\begin{array}{l}\text { Innovativeness and perceived technology security } \\
\text { are the most important factors influencing users' } \\
\text { intention to adopt internet banking. Gamification } \\
\text { moderates the relationship between customer's } \\
\text { intention to adopt internet banking and } \\
\text { customer's intention to recommend internet } \\
\text { banking in social networks }\end{array}$ \\
\hline $\begin{array}{l}\text { Bayuk and } \\
\text { Altobello } \\
(2019)\end{array}$ & $\begin{array}{l}\text { To explore the potential } \\
\text { benefits of gamification for } \\
\text { financial well-being and } \\
\text { motivation to save }\end{array}$ & $\begin{array}{l}\text { Empirical / } \\
\text { Quantitative } \\
\text { (survey and } \\
\text { experiment) }\end{array}$ & $\begin{array}{l}\text { Financial } \\
\text { apps }\end{array}$ & $\begin{array}{l}\text { Subjective knowledge, expertise with } \\
\text { financial topics, game features (social } \\
\text { vs. economic), motivation to use the } \\
\text { app, efficacy of the app and perceived } \\
\text { usefulness }\end{array}$ & $\begin{array}{l}\text { Users with experience with finance and money- } \\
\text { savings apps are motivated by both social and } \\
\text { economic features of financial applications, } \\
\text { whereas those with no experience prefer } \\
\text { economic features }\end{array}$ \\
\hline $\begin{array}{l}\text { Rahi and } \\
\text { Ghani } \\
(2019)\end{array}$ & $\begin{array}{l}\text { To investigate factors } \\
\text { influencing the adoption of } \\
\text { internet banking }\end{array}$ & $\begin{array}{l}\text { Empirical / } \\
\text { Quantitative } \\
\text { (survey) }\end{array}$ & $\begin{array}{l}\text { Internet } \\
\text { banking }\end{array}$ & $\begin{array}{l}\text { Performance expectancy, effort } \\
\text { expectancy, website design, website } \\
\text { characteristics, general self-confidence, } \\
\text { intention to adopt internet banking and } \\
\text { intention to recommend } \\
\text { Gamification (moderator) }\end{array}$ & $\begin{array}{l}\text { Performance expectancy, effort expectancy, } \\
\text { website design, website characteristics and } \\
\text { general self-confidence positively influence the } \\
\text { intention to adopt internet banking. Gamification } \\
\text { moderates the relationship between customer's } \\
\text { intention to adopt and customer's intention to } \\
\text { recommend internet banking }\end{array}$ \\
\hline
\end{tabular}




\begin{tabular}{|c|c|c|c|c|c|}
\hline Reference & Aim & $\begin{array}{l}\text { Type / } \\
\text { Research } \\
\text { design }\end{array}$ & Context & Variables studied & Key findings \\
\hline $\begin{array}{l}\text { Nasirzadeh } \\
\text { and } \\
\text { Fathian } \\
\text { (2020) }\end{array}$ & $\begin{array}{l}\text { To investigate the } \\
\text { relationship between } \\
\text { demographic and personality } \\
\text { traits of individuals and their } \\
\text { preferences for gamification } \\
\text { elements and expected } \\
\text { benefits }\end{array}$ & $\begin{array}{l}\text { Empirical / } \\
\text { Quantitative } \\
\text { (survey) }\end{array}$ & Banking & $\begin{array}{l}\text { Age, education, gender, personality } \\
\text { traits, game elements (point, level, } \\
\text { badge, reward, leaderboard, etc.) and } \\
\text { expected benefits }\end{array}$ & $\begin{array}{l}\text { Preferences toward gamification elements and } \\
\text { perceived expected benefits depend on the } \\
\text { demographic characteristics and personality traits }\end{array}$ \\
\hline
\end{tabular}


Table II. Sample characteristics

\begin{tabular}{llc}
\hline Category & & Percentage (\%) \\
\hline Gender & Men & $36.54 \%$ \\
& Women & $63.46 \%$ \\
\hline Age & $<31$ years old & $10.10 \%$ \\
& 31-40 years old & $14.42 \%$ \\
& 41-50 years old & $15.87 \%$ \\
& $>50$ years old & $59.62 \%$ \\
\hline App experience & $<3$ months & $1.44 \%$ \\
& 3-6 months & $1.44 \%$ \\
& 6-12 months & $5.77 \%$ \\
& $12-18$ months & $7.69 \%$ \\
& 18-24 months & $8.65 \%$ \\
& $>24$ months & $75 \%$ \\
\hline Frequency of app use & Almost every day & $10.10 \%$ \\
& Once in 2-3 days & $8.65 \%$ \\
& Once in 4-5 days & $3.37 \%$ \\
& Once a week & $23.08 \%$ \\
& Once a month & $37.02 \%$ \\
& Once in three months & $8.65 \%$ \\
& Once in six months & $6.25 \%$ \\
& Once a year & $2.88 \%$ \\
\hline
\end{tabular}


Table III. Formative measurement model results (first-order constructs)

\begin{tabular}{ccccccccc}
\hline \multirow{2}{*}{ Construct } & Indicator & Mean & SD & Loading & t-value & Weight & t-value & VIF \\
\hline \multirow{2}{*}{ Credit Score } & Frequency & 3.99 & 2.13 & 0.657 & 4.197 & -0.260 & 0.864 & 2.483 \\
& Importance & 4.43 & 2.18 & 0.986 & 21.912 & 1.187 & 5.721 & 2.483 \\
\hline \multirow{2}{*}{ Alerts } & Frequency & 3.77 & 2.06 & 0.743 & 6.330 & -0.114 & 0.395 & 2.635 \\
& Importance & 4.25 & 2.10 & 0.998 & 40.834 & 1.087 & 4.840 & 2.635 \\
\hline \multirow{2}{*}{ Budgets } & Frequency & 4.09 & 2.03 & 0.884 & 11.397 & 0.232 & 0.760 & 2.952 \\
& Importance & 4.58 & 2.02 & 0.991 & 24.336 & 0.802 & 2.884 & 2.952 \\
\hline \multirow{2}{*}{ Tracking } & Frequency & 5.42 & 1.85 & 0.993 & 27.726 & 0.855 & 3.402 & 2.349 \\
& Importance & 5.74 & 1.69 & 0.830 & 7.213 & 0.181 & 0.617 & 2.349 \\
\hline \multirow{2}{*}{ Personalization } & Frequency & 3.09 & 1.75 & 0.824 & 6.445 & 0.285 & 0.959 & 1.902 \\
& Importance & 3.80 & 1.93 & 0.978 & 15.234 & 0.782 & 3.019 & 1.902 \\
\hline
\end{tabular}

Note: SD: Standard deviation; VIF: Variance inflation factor. 
Table IV. Formative measurement model results (second-order constructs)

\begin{tabular}{ccccccc}
\hline Construct & Indicator & Loading & t-value & Weight & t-value & VIF \\
\hline \multirow{4}{*}{ Motivational affordances } & Credit Score & 0.680 & 8.155 & 0.542 & 4.841 & 1.210 \\
& Alerts & 0.562 & 6.477 & 0.138 & 1.204 & 1.384 \\
& Budgets & 0.584 & 6.700 & 0.154 & 1.379 & 1.486 \\
& Tracking & 0.768 & 10.248 & 0.603 & 5.625 & 1.351 \\
\hline
\end{tabular}

Note: VIF: Variance inflation factor. 
Table V. Reflective measurement model results

\begin{tabular}{|c|c|c|c|c|c|c|c|c|}
\hline Construct & Indicator & Mean & SD & $\begin{array}{l}\text { Factor } \\
\text { loading }\end{array}$ & AVE & CR & $\begin{array}{c}\text { Cronbach's } \\
\text { alpha }\end{array}$ & $\mathbf{Q}^{2}$ \\
\hline \multirow{4}{*}{ Competence } & COM1 & 4.73 & 1.60 & 0.920 & \multirow{4}{*}{0.810} & \multirow{4}{*}{0.944} & \multirow{4}{*}{0.922} & \multirow{4}{*}{0.246} \\
\hline & COM2 & 4.89 & 1.55 & 0.899 & & & & \\
\hline & COM3 & 3.94 & 1.67 & 0.860 & & & & \\
\hline & COM4 & 4.84 & 1.67 & 0.919 & & & & \\
\hline \multirow{4}{*}{ Autonomy } & AUT1 & 5.54 & 1.39 & 0.832 & \multirow{4}{*}{0.730} & \multirow{4}{*}{0.915} & \multirow{4}{*}{0.877} & \multirow{4}{*}{0.181} \\
\hline & AUT2 & 5.89 & 1.35 & 0.895 & & & & \\
\hline & AUT3 & 5.87 & 1.42 & 0.888 & & & & \\
\hline & AUT4 & 6.16 & 1.26 & 0.800 & & & & \\
\hline \multirow{8}{*}{$\begin{array}{c}\text { Autonomous } \\
\text { motivation }\end{array}$} & MOT1 & 5.40 & 1.64 & 0.860 & \multirow{8}{*}{0.679} & \multirow{8}{*}{0.944} & \multirow{8}{*}{0.931} & \multirow{8}{*}{0.315} \\
\hline & MOT2 & 5.13 & 1.70 & 0.896 & & & & \\
\hline & MOT3 & 5.31 & 1.62 & 0.715 & & & & \\
\hline & MOT4 & 4.99 & 1.61 & 0.813 & & & & \\
\hline & MOT5 & 4.61 & 1.67 & 0.826 & & & & \\
\hline & MOT6 & 4.36 & 1.70 & 0.866 & & & & \\
\hline & MOT7 & 3.69 & 1.71 & 0.725 & & & & \\
\hline & MOT8 & 4.18 & 1.68 & 0.874 & & & & \\
\hline \multirow{3}{*}{$\begin{array}{l}\text { Perceived } \\
\text { ease of use }\end{array}$} & PEOU1 & 5.37 & 1.52 & 0.968 & \multirow{3}{*}{0.946} & \multirow{3}{*}{0.981} & \multirow{3}{*}{0.972} & \multirow{3}{*}{0.267} \\
\hline & PEOU2 & 5.40 & 1.48 & 0.975 & & & & \\
\hline & PEOU3 & 5.32 & 1.60 & 0.975 & & & & \\
\hline \multirow{3}{*}{$\begin{array}{l}\text { Perceived } \\
\text { usefulness }\end{array}$} & PU1 & 5.04 & 1.58 & 0.939 & \multirow{3}{*}{0.911} & \multirow{3}{*}{0.968} & \multirow{3}{*}{0.951} & \multirow{3}{*}{0.479} \\
\hline & PU2 & 5.31 & 1.55 & 0.963 & & & & \\
\hline & PU3 & 5.23 & 1.59 & 0.961 & & & & \\
\hline \multirow{3}{*}{ Attitude } & ATT1 & 5.71 & 1.46 & 0.957 & \multirow{3}{*}{0.908} & \multirow{3}{*}{0.967} & \multirow{3}{*}{0.949} & \multirow{3}{*}{0.493} \\
\hline & ATT2 & 5.66 & 1.50 & 0.956 & & & & \\
\hline & ATT3 & 5.55 & 1.58 & 0.946 & & & & \\
\hline & BI1 & 5.70 & 1.65 & 0.888 & & & & \\
\hline Behavioral & $\mathrm{BI} 2$ & 3.74 & 1.88 & 0.872 & 0.817 & 0.930 & 0.887 & 0.493 \\
\hline & $\mathrm{BI} 3$ & 4.72 & 1.91 & 0.951 & & & & \\
\hline
\end{tabular}

Note: SD: Standard deviation; CR: Composite reliability; AVE: Average variance extract. 
Table VI. Fornell-Larcker test

\begin{tabular}{lccccccc}
\hline & $\mathbf{1}$ & $\mathbf{2}$ & $\mathbf{3}$ & $\mathbf{4}$ & $\mathbf{5}$ & $\mathbf{6}$ & $\mathbf{7}$ \\
\hline 1. Competence & $\mathbf{0 . 9 0 0}$ & & & & & & \\
2. Autonomy & 0.528 & $\mathbf{0 . 8 5 5}$ & & & & & \\
3. Autonomous motivation & 0.632 & 0.565 & $\mathbf{0 . 8 2 4}$ & & & & \\
4. Perceived ease of use & 0.593 & 0.637 & 0.538 & $\mathbf{0 . 9 7 3}$ & & & \\
5. Perceived usefulness & 0.638 & 0.537 & 0.598 & 0.676 & $\mathbf{0 . 9 5 4}$ & & \\
6. Attitude & 0.621 & 0.683 & 0.707 & 0.663 & 0.692 & $\mathbf{0 . 9 5 3}$ & \\
7. Behavioral intention & 0.552 & 0.525 & 0.634 & 0.559 & 0.682 & 0.674 & $\mathbf{0 . 9 0 4}$ \\
\hline
\end{tabular}

Note: Diagonal elements are the root squared AVE values. Elements below the diagonal are the constructs' correlations. 
Table VII. Heterotrait-monotrait (HTMT) ratios

\begin{tabular}{|c|c|c|c|c|c|c|}
\hline & Competence & Autonomy & $\begin{array}{c}\text { Autonomous } \\
\text { motivation }\end{array}$ & $\begin{array}{l}\text { Perceived } \\
\text { ease of use }\end{array}$ & $\begin{array}{l}\text { Perceived } \\
\text { usefulness }\end{array}$ & Attitude \\
\hline Autonomy & $\begin{array}{c}0.575 \\
{[0.456 ; 0.680]}\end{array}$ & & & & & \\
\hline $\begin{array}{l}\text { Autonomous } \\
\text { motivation }\end{array}$ & $\begin{array}{c}0.677 \\
{[0.548 ; 0.778]}\end{array}$ & $\begin{array}{c}0.620 \\
{[0.512 ; 0.717]}\end{array}$ & & & & \\
\hline $\begin{array}{l}\text { Perceived } \\
\text { ease of use }\end{array}$ & $\begin{array}{c}0.626 \\
{[0.506 ; 0.726]}\end{array}$ & $\begin{array}{c}0.688 \\
{[0.566 ; 0.785]}\end{array}$ & $\begin{array}{c}0.566 \\
{[0.438 ; 0.677]}\end{array}$ & & & \\
\hline $\begin{array}{l}\text { Perceived } \\
\text { usefulness }\end{array}$ & $\begin{array}{c}0.682 \\
{[0.568 ; 0.770]}\end{array}$ & $\begin{array}{c}0.578 \\
{[0.463 ; 0.685]}\end{array}$ & $\begin{array}{c}0.634 \\
{[0.512 ; 0.738]}\end{array}$ & $\begin{array}{c}0.703 \\
{[0.583 ; 0.794]}\end{array}$ & & \\
\hline Attitude & $\begin{array}{c}0.661 \\
{[0.542 ; 0.752]}\end{array}$ & $\begin{array}{c}0.746 \\
{[0.619 ; 0.841]}\end{array}$ & $\begin{array}{c}0.749 \\
{[0.665 ; 0.816]}\end{array}$ & $\begin{array}{c}0.609 \\
{[0.560 ; 0.792]}\end{array}$ & $\begin{array}{c}0.727 \\
{[0.610 ; 0.815]}\end{array}$ & \\
\hline $\begin{array}{l}\text { Behavioral } \\
\text { intention }\end{array}$ & $\begin{array}{c}0.610 \\
{[0.480 ; 0.716]}\end{array}$ & $\begin{array}{c}0.585 \\
{[0.472 ; 0.681]}\end{array}$ & $\begin{array}{c}0.694 \\
{[0.604 ; 0.771]}\end{array}$ & $\begin{array}{c}0.598 \\
{[0.471 ; 0.698]}\end{array}$ & $\begin{array}{c}0.742 \\
{[0.641 ; 0.816]}\end{array}$ & $\begin{array}{c}0.730 \\
{[0.628 ; 0.809]}\end{array}$ \\
\hline
\end{tabular}

Note: The values in brackets represent the $95 \%$ bias-corrected and accelerated confidence interval of the HTMT values. 
Table VIII. Structural model results

\begin{tabular}{lccc}
\hline \multicolumn{1}{c}{ Hypotheses } & $\boldsymbol{\beta}$ & t-value & Supported \\
\hline H1a: Motivational affordances $\rightarrow$ Competence & 0.562 & $10.553^{* * * *}$ & Yes \\
H1b: Motivational affordances $\rightarrow$ Autonomy & 0.522 & $8.960^{* * *}$ & Yes \\
H2a: Competence $\rightarrow$ Autonomous motivation & 0.463 & $5.911^{* * *}$ & Yes \\
H2b: Autonomy $\rightarrow$ Autonomous motivation & 0.321 & $4.618^{* * *}$ & Yes \\
H3a: Autonomous motivation $\rightarrow$ Perceived ease of use & 0.538 & $9.117^{* * *}$ & Yes \\
H3b: Autonomous motivation $\rightarrow$ Perceived usefulness & 0.330 & $4.169^{* * *}$ & Yes \\
H4a: Perceived ease of use $\rightarrow$ Attitude & 0.360 & $4.296^{* * *}$ & Yes \\
H4b: Perceived usefulness $\rightarrow$ Attitude & 0.449 & $5.598^{* * *}$ & Yes \\
H4c: Perceived ease of use $\rightarrow$ Perceived usefulness & 0.498 & $6.569^{* * *}$ & Yes \\
H5: Attitude $\rightarrow$ Behavioral intention & 0.602 & $11.300^{* * *}$ & Yes \\
\hline Control variables: & & & \\
Experience $\rightarrow$ Behavioral intention & -0.029 & 0.630 & \\
Frequency of app use $\rightarrow$ Behavioral intention & 0.416 & $7.954^{* * *}$ & \\
Gender $\rightarrow$ Behavioral intention & 0.043 & 0.838 & \\
Age $\rightarrow$ Behavioral intention & 0.021 & 0.422 & \\
\hline
\end{tabular}

Note: ${ }^{* * *} \mathrm{p}<0.001$ 
Appendix. Measurement scales

\begin{tabular}{|c|c|}
\hline \multicolumn{2}{|r|}{ Constructs, items and sources } \\
\hline \multicolumn{2}{|c|}{ Interaction with motivational affordances (adapted from Xi and Hamari, 2019) } \\
\hline AFF1 & The frequency of interacting with credit score in Mint \\
\hline AFF2 & The frequency of interacting with bill reminder alerts in Mint \\
\hline AFF3 & The frequency of interacting with budgets in Mint \\
\hline AFF4 & The frequency of interacting with tracking in Mint \\
\hline AFF5 & The frequency of interacting with personalization in Mint \\
\hline AFF6 & The importance of interacting with credit score in Mint \\
\hline AFF7 & The importance of interacting with bill reminder alerts in Mint \\
\hline AFF8 & The importance of interacting with budgets in Mint \\
\hline AFF9 & The importance of interacting with tracking in Mint \\
\hline AFF10 & The importance of interacting with personalization in Mint \\
\hline \multicolumn{2}{|c|}{ Competence (adapted from Xi and Hamari, 2019) } \\
\hline COM1 & I think that I am pretty good when I use this app \\
\hline COM2 & I am satisfied with my performance when I use this app \\
\hline COM3 & I feel like an expert using this app \\
\hline COM4 & I feel like a competent person when I use this app \\
\hline \multicolumn{2}{|c|}{ Autonomy (adapted from Xi and Hamari, 2019; Standage et al., 2005) } \\
\hline AUT1 & In this app I have different options \\
\hline AUT2 & I feel free to use this app \\
\hline AUT3 & I feel free to decide what activities to do in this app \\
\hline AUT4 & When I use this app, it is because I want to use it \\
\hline \multicolumn{2}{|c|}{ Autonomous motivation (adapted from Guay et al., 2000) } \\
\hline MOT1 & I use Mint because I think that this app is interesting \\
\hline MOT2 & I use Mint because I think that this app is pleasant \\
\hline MOT3 & I use Mint because this app is fun \\
\hline MOT4 & I use Mint because I feel good when using this app \\
\hline MOT5 & I use Mint because I am doing it for my own good \\
\hline MOT6 & I use Mint because I think that this app is good for me \\
\hline MOT7 & I use Mint because of personal decision \\
\hline MOT8 & I use Mint because I believe that this app is important for me \\
\hline \multicolumn{2}{|c|}{ Perceived ease of use (adapted from Davis, 1989) } \\
\hline PEOU1 & I find this app easy to use \\
\hline PEOU2 & My interaction with this app is clear and understandable \\
\hline PEOU3 & I find this app easy to interact with \\
\hline \multicolumn{2}{|c|}{ Perceived usefulness (adapted from Davis, 1989) } \\
\hline PU1 & Using this app enables me to control my finances/expenses \\
\hline PU2 & Using this app makes easier to control my finances/expenses \\
\hline PU3 & I find this app useful to control my finances/expenses \\
\hline \multicolumn{2}{|c|}{ Attitude (adapted from Taylor and Todd, 1995) } \\
\hline ATT1 & Using this app is a good idea \\
\hline ATT2 & Using this app is a wise idea \\
\hline ATT3 & I like the idea of using this app \\
\hline \multicolumn{2}{|c|}{ Behavioral intention (adapted from Venkatesh et al., 2012) } \\
\hline BI1 & I intend to continue using this app in the future \\
\hline BI2 & I will always try to use this app in my daily life \\
\hline BI3 & I plan to continue to use this app frequently \\
\hline
\end{tabular}

